\title{
Clinical and radiographic evaluation of caries depth, root resorption and furcation
}

\section{lesion in primary molars}

Avaliação clínica e radiográfica da profundidade de cárie, reabsorção radicular e lesão de furca em molares decíduos

Evaluación clínica y radiográfica de la profundidad de caries, reabsorción radicular y lesión de furca en molares primarios

\author{
Híttalo Carlos Rodrigues de Almeida \\ ORCID: https://orcid.org/0000-0001-7348-6601 \\ University of Pernambuco, Brazil \\ E-mail: hittalo.rodrigues@hotmail.com \\ Maria Cristina Valença de Oliveira \\ ORCID: https://orcid.org/0000-0002-2806-9945 \\ University of Pernambuco, Brazil \\ E-mail: mcristinavo@hotmail.com \\ Zilda Betânia Barbosa Medeiros de Farias \\ ORCID: https://orcid.org/0000-0001-9549-2260 \\ University of Pernambuco, Brazil \\ E-mail: zfarias2011@hotmail.com \\ Jade de Souza Cavalcante \\ ORCID: https://orcid.org/0000-0003-1044-2323 \\ University of Pernambuco, Brazil \\ E-mail: jadeahj@gmail.com \\ Bruna Peixoto Nogueira dos Santos \\ ORCID: https://orcid.org/0000-0003-4068-5887 \\ University of Pernambuco, Brazil \\ E-mail: brunanogueira_cd@hotmail.com \\ Rebeka Thiara Nascimento dos Santos \\ ORCID: https://orcid.org/0000-0002-0422-8593 \\ University of Pernambuco, Brazil \\ E-mail: rebeka.nsantos@gmail.com \\ Pâmella Recco Álvares \\ ORCID: https://orcid.org/0000-0003-3396-9339 \\ University of Pernambuco, Brazil \\ E-mail: pamellarecco@hotmail.com \\ Márcia Maria Fonseca da Silveira \\ ORCID: https://orcid.org/0000-0002-2611-5661 \\ University of Pernambuco, Brazil \\ E-mail: marcia.silveira@upe.br \\ Ana Paula Veras Sobral \\ ORCID: https://orcid.org/0000-0002-0801-9385 \\ University of Pernambuco, Brazil \\ E-mail: ana.sobral@upe.br
}

\begin{abstract}
Primary molars with furcation lesions have a negative impact on the child's quality of life. We determined the prevalence of furcation lesions and their influence on the root resorption process in primary molars. It is Cross-sectional study of patients aged 3 to 12 years that was apply a health questionnaire was applied and the teeth were submitted to physical examination using the International Caries Detection and Assessment System (ICDAS) and periapical radiography. Criteria for radiographic interpretation were established and assessments performed by three different specialists. The kappa coefficient measured interexaminer agreement and level of significance of 5\% was adopted for all tests. The sample consisted of 26 patients and 50 primary molars. The second molar received ICDAS score 6 in $38.5 \%$ of the sample. The interexaminer agreement was almost perfect between the radiologist and pediatric dentist for caries depth on the mesial $(K=0.97)$ and occlusal surface $(K=0.97)$; In root resorption for mesial $(K=0.89)$ and distal $(K=0.93)$. The detection of furcation lesions was present in $42.3 \%$ of the sample; $50 \%$ of the teeth had at least $1 / 3$ of the mesial root resorbed and $75 \%$ of the distal root and the presence of furcation lesions in primary molars influenced root resorption. Keywords: Tooth deciduous; Dental caries; Dental pulp diseases; Rooth resorption.
\end{abstract}




\begin{abstract}
Resumo
Molares decíduos com lesões de furca têm impacto negativo na qualidade de vida da criança. Determinamos a prevalência de lesões de furca e sua influência no processo de reabsorção radicular em molares decíduos. Trata-se de um estudo transversal de pacientes de 3 a 12 anos em que foi aplicado um questionário de saúde e os dentes foram submetidos a exame físico por meio do Sistema Internacional de Detecção e Avaliação de Cárie (ICDAS) e radiografia periapical. Critérios para interpretação radiográfica foram estabelecidos e avaliações realizadas por três diferentes especialistas. O coeficiente kappa mediu a concordância interexaminadores e o nível de significância de $5 \%$ foi adotado para todos os testes. A amostra foi composta por 26 pacientes e 50 molares decíduos. O segundo molar recebeu pontuação ICDAS 6 em 38,5\% da amostra. A concordância interexaminador foi quase perfeita entre o radiologista e o odontopediatra para a profundidade da cárie na superfície mesial $(K=0,97)$ e oclusal $(K=0,97)$; Na reabsorção radicular para mesial $(K=0,89)$ e distal $(K=0,93)$. A detecção de lesões de furca esteve presente em $42,3 \%$ da amostra; $50 \%$ dos dentes tiveram pelo menos $1 / 3$ da raiz mesial reabsorvida e $75 \%$ da raiz distal e a presença de lesões de furca nos molares decíduos influenciou a reabsorção radicular.
\end{abstract}

Palavras-chave: Dente decíduo; Cárie dentária; Doenças da polpa dentária; Reabsorção de raízes.

\title{
Resumen
}

Los molares primarios con lesiones de furca tienen un impacto negativo en la calidad de vida del niño. Determinamos la prevalencia de lesiones de furca y su influencia en el proceso de reabsorción radicular en molares temporales. Se trata de un estudio transversal de pacientes de 3 a 12 años a los que se les aplicó un cuestionario de salud y los dientes fueron sometidos a examen físico mediante el Sistema Internacional de Detección y Evaluación de Caries (ICDAS) y radiografía periapical. Se establecieron criterios para la interpretación radiográfica y se realizaron evaluaciones por tres especialistas diferentes. Para todas las pruebas se adoptó el coeficiente kappa medido entre examinadores y el nivel de significancia del 5\%. La muestra estuvo formada por 26 pacientes y 50 molares temporales. El segundo molar recibió un puntaje ICDAS de 6 en el 38,5\% de la muestra. La concordancia entre examinadores fue casi perfecta entre el radiólogo y el odontopediatra para la profundidad de la caries en la superficie mesial $(K=0,97)$ y oclusal $(K=0,97)$; En reabsorción radicular para mesial $(K=0,89)$ y distal $(K=0,93)$. La detección de lesiones de furca estuvo presente en el $42,3 \%$ de la muestra; El 50\% de los dientes tenían al menos 1/3 de la raíz mesial reabsorbida y el $75 \%$ de la raíz distal y la presencia de lesiones de furca en los molares temporales influyó en la reabsorción radicular.

Palabras clave: Diente de hoja caduca; Caries dental; Enfermedades de la pulpa dental; Reabsorción de raíces.

\section{Introduction}

Physiologic tooth resorption is essential during the process of rhizolysis of primary teeth, which results in their exfoliation and in the subsequent eruption of the permanent successors (Consolaro 2011; Harokopakis-Hajishengallis 2007, Mulia, Indiarti \& Budiarjo 2018). On the other hand, root resorption caused by cariogenic processes is pathologic and can imply severe damage to dental tissues (Vieira-Andrade et al. 2012).

The inter-radicular region of primary molars is an area that undergoes intense modifications related to root resorption (Bolan \& Rocha 2007). Foramina are found in this region, which are formed by the persistence of blood vessels that reach the pulp and that originate in the pulp chamber floor, passing through the inter-radicular dentin and reaching the periodontal ligament in the furcation area (Bolan \& Rocha 2007; Lugliè et al. 2012). When a primary molar suffers pulp aggression, foramina facilitate invasion of the inter-radicular region by products derived from the bacterial metabolism, causing an inflammatory reaction in alveolar bone that results in the destruction of supporting tissues, bone resorption, and clinical attachment loss, a condition called furcation lesion (Lugliè et al. 2012; Ringelstein \& Seow, 1989; Smaïl-Faugeron et al. 2018).

The diagnosis of furcation lesions is made based on the clinical condition of the primary tooth and radiographic examination to identify the degree of root resorption, the condition of the pulp floor, and the mineralization stage of the permanent tooth (Consolaro 2011). Pulp sensitivity testing is not recommended because it is not objective and may cause anxiety in the child (Huth et al. 2005). Furcation lesions are intimately related to the pericoronary follicle of the permanent tooth germ and can accelerate the root resorption of primary teeth, with consequent tooth loss because of persistence of the inflammatory stimulus and continuing pathologic resorption (Bolan \& Rocha 2007; Harokopakis-Hajishengallis 2007; Smaïl-Faugeron et al. 2018;

Vieira-Andrade et al. 2012).

Studies evaluating the presence of furcation lesions and their relationship with root resorption are necessary because of 
the anatomic particularities of primary teeth. The aim of the present study was to radiographically assess the prevalence of furcation lesions and their influence on the root resorption process in primary molars.

\section{Methodology}

This cross-sectional study was approved by the Ethics Committee of University of Pernambuco, Camaragibe, Pernambuco, Brazil (number 3.306.892/19), and was conducted in accordance with the Declaration of Helsinki. Children of both sexes aged 3 to 12 years, who sought the Pediatric Dentistry Clinic of University of Pernambuco between August and November 2019, were included. Special-needs patients, patients who were not accompanied by a responsible person, patients with established permanent dentition and healthy teeth, and patients who did not collaborate during the visit were excluded.

Clinical Examination - Clinical examination was performed by a calibrated pediatric dentist with experience in the diagnosis of healthy and carious teeth. The teeth were assessed using scores 0 to 6 of the International Caries Detection and Assessment System (ICDAS). Examination was performed in a clinical setting under refracted light using mirrors and Who Millennium Probe (Golgran, Indústria e Comércio Golgran da Instrumental Odontológico Ltda., São Paulo, Brazil). The following data were collected: sex, age, oral health, eating habits, and socioeconomic condition.

Pilot Study - To establish the exposure time for radiographic examination, the molar region of a dry human mandible was exposed for 0.3, 0.4 and 0.5 seconds. The films were processed in a standardized manner and the radiographs were analyzed separately by two experienced examiners. The enamel/dentin junction and bone structure of teeth were assessed and the radiograph exposed for 0.3 seconds was selected for all clinical conditions. The interexaminer kappa coefficient was 0.90 .

Radiographic Examination - Periapical radiography was chosen since interproximal radiography would not permit visualization of root resorption or of the relationship between the root of the primary tooth and permanent successor germ in these cases. Radiography was performed using a pediatric positioner (Indusbello ${ }^{\circledR}$ ) and an E-speed infant periapical film (number 2) $\left(\right.$ Carestream $\left.{ }^{\circledR}\right)$. The radiographs were processed by the temperature-time method using Carestream ${ }^{\circledR}$ developer and fixer. A lead apron and thyroid shield $\left(\mathrm{N}\right.$ Martins ${ }^{\circledR}$ ) was used in all children.

Radiographic interpretation - For radiographic analysis and interpretation, the caries depth, degree of root resorption of the primary tooth, and presence or absence of furcation lesions were classified. Caries depth was assessed using the criteria adapted from Nielsen et al. 1996 (Table 1).

Table 1: Scores assigned for the evaluation of caries depth.

\begin{tabular}{|l|l|}
\hline Score & Description \\
\hline 0 & Healthy surface \\
\hline 1 & Caries in the outer one-half of enamel \\
\hline 2 & Caries extending from the inner portion of enamel to the enamel-dentin junction \\
\hline 3 & Dentinal caries \\
\hline 4 & Dentinal caries with pulpal involvement \\
\hline 5 & Recurrence of caries \\
\hline
\end{tabular}

Source: Authors. 
Root resorption was classified according to the affected third of the mesial or distal roots of primary molars (Table 2).

Table 2: Classification of rhizolysis of multiradicular primary teeth.

\begin{tabular}{|l|l|}
\hline Score & Description \\
\hline 0 & No resorption \\
\hline 1 & Resorption of $1 / 3$ of the root \\
\hline 2 & Resorption of $2 / 3$ of the root \\
\hline 3 & Total root resorption \\
\hline
\end{tabular}

Source: Authors.

The images were coded and evaluated individually by three examiners ( 1 - radiologist; 2 - orthodontist; 3 - pediatric dentist) using a 24-inch LCD monitor in a dimly lit room. The examiners evaluated one radiograph at a time, totaling 20 images per day, to avoid visual fatigue, with an interval of at least 5 days between assessments. Each examiner analyzed 50 molars, 50 foramina, 150 surfaces (mesial, occlusal and distal), and 100 mesial and distal roots.

Statistical Analysis - The data were organized using the Statistical Package for the Social Sciences (SPSS 20.0) and submitted to descriptive analysis. The kappa coefficient was used to evaluate agreement between radiographic assessments (Landis \& Koch, 1977). A level of significance of $5 \%$ was adopted for all tests $(\mathrm{P}<0.0005)$.

\section{Results}

Forty-two patients were evaluated; 8 were excluded because their permanent dentition was already established, 5 because they had no caries, and 3 because they did not collaborate with the radiographic examination. The final sample consisted of 26 patients.

Radiographic analysis comprised 26 periapical radiographs with 50 primary molars, including 37 mandibular primary molars (8 right first molars, 10 left first molars, 9 right second molars, and 10 left second molars) and 13 maxillary primary molars ( 3 right first molars, 3 left first molars, 4 right second molars, and 3 left second molars).

The sample consisted of $57.7 \%(\mathrm{n}=15)$ girls and $42.3 \%(\mathrm{n}=11)$ boys. The patients ranged in age from 4 to 11 years, with a mean of 7.12 and median of 7.0 years. The most common age group was 4-7 years, corresponding to $69.2 \%$ of the sample. A mixed dentition was observed in $80.8 \%(\mathrm{n}=21)$ of the sample and primary dentition in $19.2 \%(\mathrm{n}=5)$. The consumption of cariogenic foods $\geq 4$ times per day was reported by $76.9 \%$ of the patients and a frequency of daily tooth brushing $\leq 1$ was observed in $57.7 \%$ of the sample. The ICDAS scores are described in Table 3. 
Table 3: Classification of the teeth according to the International Caries Detection and Assessment System (ICDAS).

\begin{tabular}{|c|c|c|}
\hline ICDAS score & $\mathbf{n}$ & $\%$ \\
\hline \multicolumn{3}{|c|}{ Primary first molar } \\
\hline 1 & 3 & 12.5 \\
\hline 2 & 1 & 4.2 \\
\hline 3 & 3 & 12.5 \\
\hline 4 & 9 & 37.5 \\
\hline 5 & 0 & 0.0 \\
\hline 6 & 8 & 33.3 \\
\hline \multicolumn{3}{|c|}{ Primary second molar } \\
\hline 1 & 4 & 15.4 \\
\hline 2 & 3 & 11.5 \\
\hline 3 & 3 & 11.5 \\
\hline 4 & 3 & 11.5 \\
\hline 5 & 3 & 11.5 \\
\hline 6 & 10 & 38.6 \\
\hline
\end{tabular}

Source: Authors.

With respect to caries depth, the kappa coefficient indicated almost perfect agreement between examiners 1 and 3 for the mesial $(\mathrm{K}=0.97)$ and occlusal surface $(\mathrm{K}=0.97)$. No agreement between examiners was observed for the distal surface. Analysis of root resorption showed almost perfect agreement between examiners 1 and 3 for the mesial (K=0.89) and distal surface $(\mathrm{K}=0.93)$. There was perfect agreement between the three examiners in detecting furcation lesions $(\mathrm{K}=1)$. The interexaminer agreement is shown in Table 4.

Table 4: Agreement between the three examiners for caries depth according to surface, root resorption, and presence of furcation lesions.

\begin{tabular}{|c|c|c|}
\hline Variable & Kappa & p-value \\
\hline \multicolumn{3}{|c|}{ Caries of mesial surface } \\
\hline Ex1 x Ex2 & $*$ & $*$ \\
\hline $\operatorname{Ex} 1 \times \operatorname{Ex} 3$ & 0.972 & $<0.001$ \\
\hline $\operatorname{Ex} 2 \times \operatorname{Ex} 3$ & $*$ & $*$ \\
\hline \multicolumn{3}{|c|}{ Caries of distal surface } \\
\hline Ex1 x Ex2 & $*$ & $*$ \\
\hline $\operatorname{Ex} 1 \times \operatorname{Ex} 3$ & $*$ & $*$ \\
\hline $\operatorname{Ex} 2 \times \operatorname{Ex} 3$ & $*$ & $*$ \\
\hline \multicolumn{3}{|c|}{ Caries of occlusal surface } \\
\hline Ex1 x Ex2 & 0.763 & $<0.001$ \\
\hline Ex1 $x$ Ex3 & 0.974 & $<0.001$ \\
\hline $\operatorname{Ex} 2 \times \operatorname{Ex} 3$ & 0.790 & $<0.001$ \\
\hline \multicolumn{3}{|c|}{ Mesial root resorption } \\
\hline Ex1 x Ex2 & 0.588 & $<0.001$ \\
\hline Ex1 $x$ Ex3 & 0.890 & $<0.001$ \\
\hline $\operatorname{Ex} 2 \times \operatorname{Ex} 3$ & 0.623 & $<0.001$ \\
\hline \multicolumn{3}{|c|}{ Distal root resorption } \\
\hline Ex1 x Ex2 & 0.599 & $<0.001$ \\
\hline $\operatorname{Ex} 1 \times \operatorname{Ex} 3$ & 0.939 & $<0.001$ \\
\hline $\operatorname{Ex} 2 \times \operatorname{Ex} 3$ & 0.548 & $<0.001$ \\
\hline \multicolumn{3}{|c|}{ Presence of furcation lesions } \\
\hline Ex1 x Ex2 & 1.0 & $<0.001$ \\
\hline Ex1 $x$ Ex3 & 1.0 & $<0.001$ \\
\hline $\operatorname{Ex} 2 \times \operatorname{Ex} 3$ & 1.0 & $<0.001$ \\
\hline
\end{tabular}

(*) not calculable. Source: Authors 
Furcation lesions were present in $42.3 \%$ of the patients analyzed $(n=11)$. The mean age of the sample was 6.6 years. These lesions were detected in $28 \%$ of the teeth evaluated ( $n=14$ ) (Figure 1).

Figure 1 - Left primary mandibular first molar with furcation lesions. Assessment of caries depth revealed score 4 on the mesial surface, score 3 on the occlusal surface, and score 4 on the distal surface. Root resorption was scored as 1 for the mesial root and as 2 for the distal root. Note the attachment loss and bone resorption in the inter-radicular region. Radiation source: periapical xray; filters: unfiltered; $\mathrm{kV}$ levels: $65 \mathrm{kV}$.

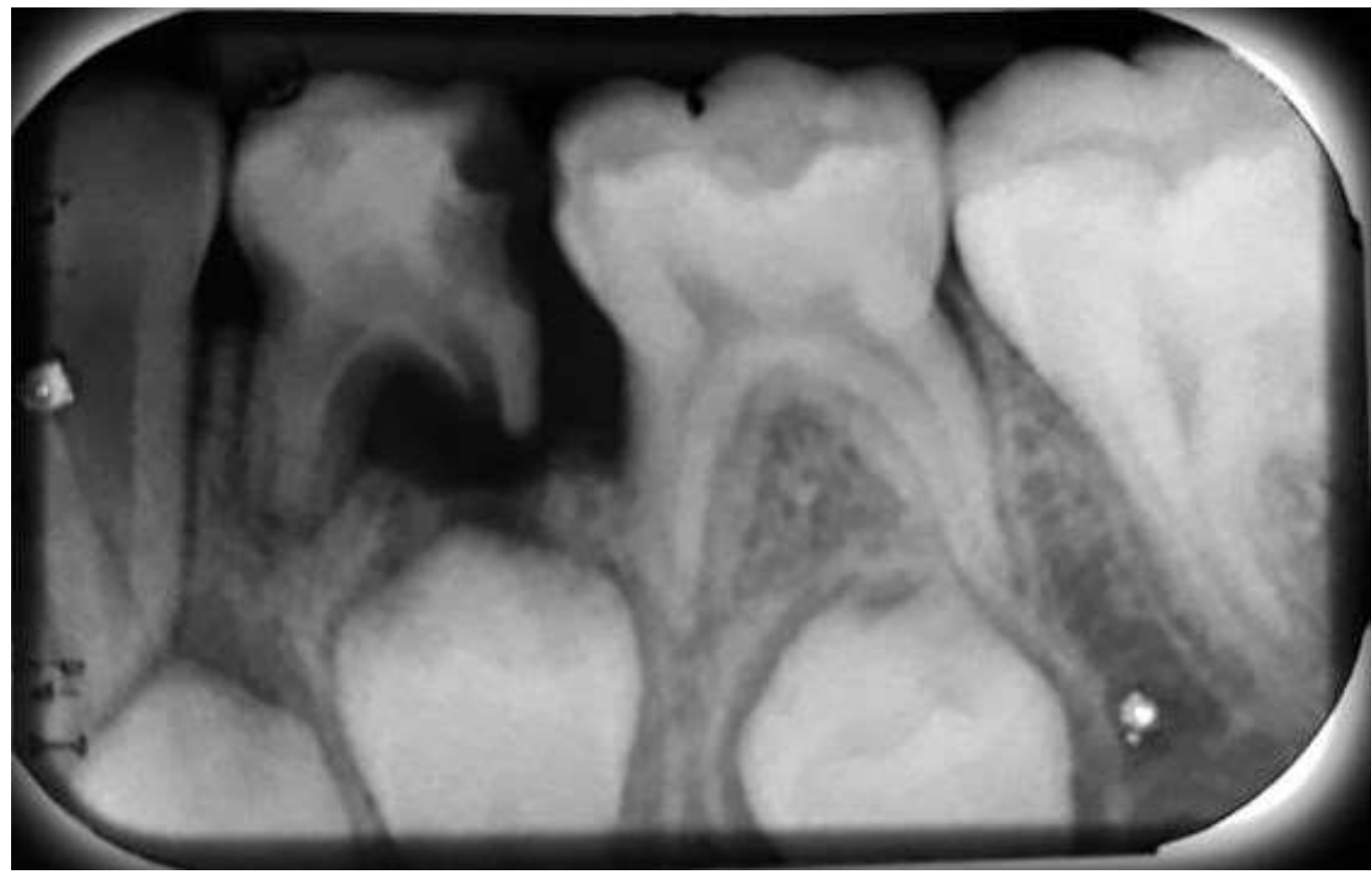

Source: Authors.

The mandibular arch was the most affected site $(n=13)$, with a similar distribution between primary first $(n=7)$ and second molars $(\mathrm{n}=6)$. Only one maxillary primary molar was diagnosed with a furcation lesion. The correlation between furcation lesions and root resorption was evaluated for examiners 1 and 3 (Table 5) who obtained the highest agreement in the radiographic assessment. For both examiners, $50 \%$ of the teeth had at least $1 / 3$ of the mesial root resorbed and $75 \%$ of the distal root. 
Table 5: Correlation between furcation lesions and root resorption according to examiners 1 (radiologist) and 3 (pediatric dentist).

\begin{tabular}{|lcc|}
\hline Variable & Foramina (n) & \% \\
\hline Mesial root resorption (Examiner 1) & & 50.0 \\
\hline No resorption & 8 & 18.75 \\
\hline Resorption of $1 / 3$ of root & 3 & 6.25 \\
\hline Resorption of $2 / 3$ of root & 1 & 25.0 \\
\hline Total root resorption & 4 & \\
\hline Distal root resorption (Examiner 1) & & 25.0 \\
\hline No resorption & 4 & 37.5 \\
\hline Resorption of $1 / 3$ of root & 6 & 12.5 \\
\hline Resorption of $2 / 3$ of root & 2 & 25.0 \\
\hline Total root resorption & 4 & \\
\hline Mesial root resorption (Examiner 3) & & 50.0 \\
\hline No resorption & & 12.5 \\
\hline Resorption of $1 / 3$ of root & 8 & 12.5 \\
\hline Resorption of $2 / 3$ of root & 2 & 25.0 \\
\hline Total root resorption & 2 & \\
\hline Distal root resorption (Examiner 3) & 4 & \\
\hline No resorption & & 25.0 \\
\hline Resorption of $1 / 3$ of root & & 31.25 \\
\hline Resorption of $2 / 3$ of root & 4 & 18.75 \\
\hline Total root resorption & 5 & 25.0 \\
\hline
\end{tabular}

Source: Authors.

\section{Discussion}

In the present study, the highest ICDAS score was obtained for the primary second molar. This finding can be explained by the posterior position of this tooth in the arch in relation to the other teeth, its inherent anatomic features, the high consumption of cariogenic foods, and the low frequency of tooth brushing. The susceptibility of the primary teeth to caries is related to diet, oral hygiene, and tooth morphology (Pinto et al. 2020). Cariogenic food consumption favors biofilm accumulation on the occlusal surface which, together with inadequate oral hygiene, leads to the progression of caries disease. In addition, the primary first and second molars exhibit anatomic differences, with the pits and fissures of the second molar being deep and less coalescent (Gunraj, 1999).

The peculiar anatomic features of primary teeth such as the lesser enamel and dentin thickness, greater permeability of these tissues and lower hardness and resistance contribute to the rapid progression of caries to the pulp tissues, triggering an inflammatory process and favoring root resorption (Consolaro, 2011; Harokopakis-Hajishengallis, 2007; Ringelstein \& Seow, 1989). The dental pulp suffers aggression from caries and the microorganisms present cause an inflammatory process which, when it becomes chronic, is histologically characterized by granulation tissue (ElSalhy, Azizieh \& Raghupathy, 2012; Farges, Alliot-Licht \& Renard, 2015). In primary molars, this infection spreads quickly to the inter-radicular region because of the lesser thickness of the pulp chamber floor, presence of foramina, and wide dentinal tubules in the furcation area (Bolan \& Rocha, 2007; Arikan, Sonmez \& Sari, 2016). As a consequence, bone loss occurs in the inter-radicular area, which is one of the first signs of compromised pulp (Arikan, Sonmez \& Sari, 2016; Farges, Alliot-Licht \& Renard, 2015).

The primary molars analyzed radiographically in this study were decayed. According to the literature, caries associated with pulpal involvement is approximately seven times more likely to cause root resorption (Harokopakis-Hajishengallis, 2007). The agreement between the radiologist and pediatric dentist was higher for the radiographic analysis of root resorption and caries depth on the mesial and occlusal surfaces because of the clinical experience of these professionals with primary teeth and 
radiographic interpretation. On the other hand, there was no agreement between the three examiners in the radiographic assessment of caries depth on the distal surface of primary molars. This result might be related to the radiographic technique used in the study since children do not possess the curve of Spee, a fact impairing biting during interproximal radiographic examination. In addition, the permanent first molar erupts on the distal side of the primary teeth and has a greater radiopacity than dentin and enamel, a fact that may mask the identification of caries on the distal surfaces of the primary second molars (Gunraj, 1989).

The presence of a cavity in dentin accompanied by pulpal involvement can cause the destruction of supporting tissues and attachment loss in the inter-radicular space by allowing bacterial leakage into the inter-radicular region, a condition called furcation lesion (Farges, Alliot-Licht \& Renard, 2015). The high permeability of the pulp chamber floor contributes to the easy invasion of the inter-radicular region by products derived from inflammation, pulp necrosis, and bacterial metabolism (Arikan, Sonmez \& Sari, 2016; Bolan \& Rocha, Ringelstein \& Seow, 1989).

In the present study, furcation lesions were present in $28 \%$ of decayed primary molars. This clinical situation agrees with previous studies that define these foramina as structures that connect the pulp with the inter-radicular region, establishing a passage for bacterial toxins that causes damage to the pulp chamber floor (Arikan, Sonmez \& Sari, 2016; Bolan \& Rocha, Ringelstein \& Seow, 1989). Furcation lesions are easily identified by radiographic examination of the mandibular primary dentition, probably due to the bone density and anatomic particularities of the region. In the maxillary dental arch, the radiopacity of the palatal root casts a shadow in the inter-radicular region, impairing its visualization. In both arches, the diagnosis of furcation lesions should consider the caries depth determined by clinical and radiographic examination.

The relationship of furcation lesions with the mean age of the patients agrees with previous studies that suggested the persistence of untreated caries to result in the early loss of primary tooth, affecting the sequence of eruption of the permanent successors (Arikan, Sonmez \& Sari, 2016; Vieira-Andrade, 2012). Thus, pathologic root resorption is accelerated in the presence of furcation lesions in 6- to 8-year-old children and may lead to early tooth loss before the age of physiologic exfoliation is reached.

The resorption due to caries is pathologic and its main characteristic is the absence of renewal of mineralized tissues (Consolaro, 2011). Close to the bone surface, the blood vessels comprising the microcirculation provide the conditions for installation of inflammatory infiltrate resulting from the vascular-exudative events triggered by the action of an aggressive agent (Harokopakis-Hajishengallis, 2007).

Physiologic resorption of the primary tooth is triggered by chemical mediators of osteoclasia and growth factors present in the pericoronary follicle of the permanent tooth germ (Consolaro, 2011; Harokopakis-Hajishengallis, 2007). However, in the presence of furcation lesions, root resorption is accelerated by the action of prostaglandins, epidermal growth factors, interleukin 1 and BMP-4 present in the pericoronary follicle of the permanent tooth, as well as by the invasion of bacteria through the interradicular region (ElSalhy, Azizieh \& Raghupathy, 2012).

Primary teeth with furcation lesions are lost prematurely since the treatment of choice is tooth extraction (Prove, Symons \& Meyers, 1992). Granulation tissue forms in the inter-radicular region (ElSalhy, Azizieh \& Raghupathy, 2012; Farges, AlliotLicht \& Renard, 2015); if not treated, the consequences of infection for the germ of the permanent successor include an inflammatory follicular cyst, tooth malformation and enamel hypoplasia, conditions that can compromise the child's general health.

Endodontic treatment of furcation lesions has been described in the literature (Lugliè et al. 2012), but is contraindicated because of the degree of porosity of the dentin matrix of the primary tooth, which can lead to a foreign body reaction due to the intense cellular reactivity observed in children. The toxic products used in endodontic treatment, associated with the greater 
natural permeability of the pulp chamber floor of primary teeth, can cause chemical irritation of cells and tissues in the interradicular region and trigger clinically important inflammatory reactions (Harokopakis-Hajishengallis, 2007).

The importance of identifying furcation lesions upon radiographic examination is related to the close relationship of the primary tooth with the pericoronary follicle of the permanent tooth germ. Thorough clinical assessment including intra- and extraoral clinical and radiographic examinations is necessary so that the most conservative and most adequate intervention can be adopted in each case.

\section{Conclusion}

The depth of caries in primary teeth leads to the presence of a furcation lesion that influences root resorption. This information should be used by radiologists and dentistry to guide the use of criteria in radiographic evaluation and treatment decisions.

\section{Acknowledgments}

Coordenação de Aperfeiçoamento de Pessoal de Nível Superior (CAPES-BR).

\section{Declaration of Competing Interest}

The authors that they have no know competing financial interests or personal relationships that could have appeared to influence the work reported in this paper.

\section{References}

Arikan, V., Sonmez, H., \& Sari, S. (2016). Comparison of two base materials regarding their effect on root canal treatment success in primary molars with furcation lesions. BioMed Research International, 13(1), 1-7.

Bolan, M., \& Rocha, M. J. (2007). Histopathologic study of physiological and pathological resorptions in human primary teeth. Oral Surg Oral Med Oral Pathol Oral Radiol Endod, 104(5), 680-685.

Consolaro, A. (2011). The concept of root resorptions or Root resorptions are not multifactorial, complex, controversial or polemical. Dental Press $J$ Orthod,16(8),19-24.

ElSalhy, M., Azizieh, F., \& Raghupathy, R. (2012). Cytokines as diagnostic markers of pulpal inflammation. International Endodontic Journal, 46(6), 573-580.

Farges J. C., Alliot-Licht B., \& Renard E. (2015). Dental pulp defence and repair mechanisms in dental caries. Mediators Inflamm, $23(2)$, 51-57.

Gunraj, M. Dental root resorption. (1999). Oral Surg Oral Med Oral Pathol Oral Radiol Endod, 88, 647-653.

Harokopakis-Hajishengallis, E. (2007). Physiologic root resorption in primary teeth: molecular and histological events. J Oral Sci, 49(1), 1-12.

Huth K. C., Paschos E., Hajek-Al-Khatar N., et al. (2005). Effectiveness of 4 pulpotomy techniques - Randomized controlled trial. J Dent Res; 14(2), 11441148 .

Kramer, P. F., Faraco, I. M., \& Meira, R. (2003). A SEM investigation of accessory foramina in the furcation areas of primary molars. J Clin Pediatr Dent, 27(1), 157-162.

Landis J. R., \& Koch G. G. (1977). The measurement of observer agreement for categorical data. Biometrics, 33(1), $159-174$.

Lugliè, P. F., Grabesu, V., Spano, G., \& Lumbau, A. (2012). Accessory foramina in the furcation area of primary molars. A SEM investigation. European Journal of Paediatric Dentistry, 13(4), 329-332.

Mulia, D. P., Indiarti, I. S., \& Budiarjo, S. B. (2018). Effect of root resorption of primary teeth on the development of its permanent successors: An evaluation of panoramic radiographs in 7-8 year-old boys. Journal of Physics: Conference Series, 3(2), 1073:1075.

Nielsen, L. L., Hoernoe, M., \& Wenzel, A. (1996). Radiographic detection of cavitation in approximal surfaces of primary teeth using a digital storage phosphor system and conventional film, and the relationship between cavitation and radiographic lesion depth: an in vitro study. Int J Paediatr Dent, 6(3), 167-172.

Pinto, L. M. C. P., Maluf, E. M. C. P., Inagaki, L. T., Pascon, F. M., Puppin-Rontani, R. M., \& Jardim Júnior, E. G. (2020). Dental caries investigation in children controlled for a educative and preventive oral health program. Oral Health and Prev Dent, 18(3), 583-592.

Prove, S. A., Symons, A. L., \& Meyers, I. A. (1992). Physiological root resorption of primary molars. J Clin Pediatr Dent, ;16(3), $202-206$. 
Research, Society and Development, v. 10, n. 5, e13610514818, 2021

(CC BY 4.0) | ISSN 2525-3409 | DOI: http://dx.doi.org/10.33448/rsd-v10i5.14818

Ringelstein, D., \& Seow, W. K. (1989). The prevalence of furcation foramina in primary molars. Ped Dent, 11(1), 198-201.

Smaïl-Faugeron, V., Glenny, A. M., Courson, F., Durieux, P., Muller-Bolla, M., \& Fron Chabouis, H. (2018). Pulp treatment for extensive decay in primary teeth. Cochrane Database of Systematic Reviews, 5(5), 3-20.

Vieira-Andrade, R. G., Drumond, C. L., Alves, L. P., Marques, L. S., \& Ramos-Jorge, M. L. (2012). Inflammatory root resorption in primary molars: prevalence and associated factors. Braz Oral Res, 26(4), 335-340. 